\title{
THE SERUM DIAGNOSIS OF SYPHILITIC DISEASES.*
}

\author{
EDWARD E. MAYER, A.M., M.D. AND FREDERICK PROESCHER, M.D. \\ PITTSBURG.
}

Every new laboratory method requires confirmation from many workers before being accepted as an established aid to investigation. The Wassermann syphilis reaction seems now to have reached a stage where it can be used as an actual laboratory aid in diagnosis; and, therefore, as it has been but sparingly commented on in American journals, a brief account of its significance will not come amiss.

To make this reaction plain to every physician we begin with the main fact to be remembered, namely that all such biologic experiments are physicochemical in their essential nature. This does not imply, however, that the technic is as easy as an ordinary chemical experiment. In order that the reaction may be understood, moreover, certain terms must be made clear.

An antibody is the reaction product formed in the blood of an animal when a solution of some substance, toxic or otherwise, is injected into it. This antibody generally combines with the injected substance, called the antigen, to form a compound. If these compounds are insoluble it is called a precipitin. If the injected substance is a suspension of bacteria, and these bacteria are dissolved by the antibody, bacteriolysins are formed; if they are erythrocytes, hemolysins are formed, causing hemolysis or a "laking" of the blood. When we speak of an agglutinin we imply that the injected cells have been agglutinated and not dissolved.

In the complement tests we use as antigen or receptor a known substance, add to it the fluid we are testing and some guinea-pig serum. If the fluid to be tested is of like nature to the receptor we do not obtain hemolysis when this solution, properly prepared, is added to heated hemolytic rabbit serum and washed sheep's corpuscles. This is due to the fact that there has already been a binding of the complement, the antigen and the serum tested being homologous.

In 1901 Bordet and Gengou discovered that if emulsions of bacteria were mixed with inactivated immune serum and a complement added, this complement bound itself with the bacteria, with the result that any red blood corpuscle filled with its hemolytic amboceptor would not dissolve. This result was due to the fact that on account of the previous

\footnotetext{
*Read at the meeting of the Allegheny County Medical Society, June 16, 1908.
} 
binding of complements the emulsions of bacteria were no longer available for the hemolytic amboceptor. 'Three rears later, in 1905, Neisser and sachs used this method for the detection of minute quantities of albumin.

Wassemanm and Bruck, by successive steps, not only gave a clinical trend to these ofservations but succeeded in determining that extracts from infeeted orrans could be used as well as solutions of bacterial extracts, a method which they first employed as an adrance on Bordet and Gengou's original bacterial suspensions. 'There results led them, in conjunction with $A$. Neisser, to discover a serum diagnosis of syphilis -the Wassermann syphilis reaction.

'They showed that in the serum of syphilitic apes there occurred a substanee which was not present in normal serum, and later that when the blood serum of syphilitic individuals was added to extracts from the liver' of a syphilitic new-born the complement was bound.

This reaction was confirmed by others, it being shown to be specific and almost invariably negative with sera from normal persons so that it could be looked on as being a reaction of amboceptor-like reaction products on substances which were directly eonnected with the original luetic infection and which must be present in extracts of syphilitic organs used for the complement fixation.

A number of later observations tended to show that it was not specific for the antigens of the syphilitic reaction, and, therefore. for the amboceptor nature of the serum contents specific for lues. Marie and Levaditi found that a similar reaction, though a woaker one, could be procheed witli extracts from normal liver. Weil, l'laut, Braun, rolk, Pötzl, Michaelis and others showed that antigens for luctic sera were found in non-luetic organs. Landsteiner and Müller liscovered independently that lipoid substances, especially lecithin, as well as liver extracts, produced this reaction. Pötzl, Sachs and Almann found that a sodium oleate solution also produced this reaction. Benerke utilized this discovery to explain the increased efficiency of fetal livers in the production of the reaction, as they contain many fat drops surrounded by an invisible soap membrane. He believes this fact to be confirmatory of Michaelis' opinion that Wassermann's reaction "does not reveal the presence of an antibody against the cause of syphilis or its poisons, but some other substance which has no direct connection with the cause of the syphilis, lut which is found more abundantly in. or more easily extracterl from, spphilitic organs than from normal ones."

Though Wasscrmann regarded this reaction at first as denoting the presence of an antibody, neither he nor his pupils, in their later conclu- 
sions, regarded it as being indicative of the action of an antibody in the sense of a recuperative action (as in diphtheria). That the lipoid element in this reaction does not negative its value is readily apparent; on the contrary, it perhaps explains the lipoid degeneration in parasphilitic discases. The results in over 1,000 cases examined, in which the diagnostic value of the reaction was shown, surely inclines us to accept it as of value despite laboratory criticisms concerning its actual scientific foundation, for these results show that normal individuals never give the reaction, and about 80 per cent. of syphilitic cases do. Wassermann emphasizes especially the fact that it is a reaction only occurring with syphilitic serum, no matter of what nature the extracts which are used in conjunction with it, and that it is as important as the Widal reaction in typhoid fever.

It is probable that this reaction is that of a body formed in slight amounts in a healthy individual, which, however, defies detection until increased by syphilitic infection.

T'he alkalinity of the serum scems to have an influence in the reaction, it being prevented by $1 / 800$ to $1 / 3200$ sodium hydrate solution and increased by $1 / 1000$ to $1 / 2000$ hydrochloric acid solution (Sachs and Altmann). In this strength these reagents have no action on hemolysis. Never, however, did non-syphilitic serum become positive by the addition of hydrochloric acid solutions (lipoid action under lessened alkalinity).

Our technic, which was according to Wassermann and Sachs and Nltmann, was briefly as follows: 4 to 5 c.e. of blood was obtained by venesection, 0.5 to 1 c.e. of serum being enough for four to five tubes with decreasing quantities of antigen. As antigen, we employed a freshly prepared 1 per cent. solution of sodium oleate in 0.85 per cent. sodium chlorid solution. This substance, in itself hemolytic, is inhibited by blood serum in proper proportions (Noguchi and Liebermann); and as Sachs and Altmann have showed, it prevents the hemolytic action of the complement. The anticomplement action of the blood serum plays no part in these experiments, as the complement fixation occurs below the inhibition zone in question. The difference between the inhibition of soap hemolysis by syphilitic and normal serum is slight; Sachs and Altmann found it so, and we can confirm their findings. The best ambo(eptor is the serum of a rabbit injected with calf's blood and rendered inartive by heating to $56 \mathrm{C}$.; this is known to hemolyze sheep's blood. Three injections of 50 to 80 c.c. of calf's blood intraperitoneally sufflice in from two to three wecks to furnish a sufficiently strong hemolytic serum. Two to two and one-half amboceptor units are sufficient. It 
is necessary to value accurately the hemolytic amboceptors used. The sheep's blood is washed several times with normal salt solution. To actirate the amboceptor, fresh guinea-pig serum is used. The complement can be kept for about a week, if 1 per cent. sodium chlorid is added and then frozen. To carry out the reaction $0.6,0.5,0.4,0.3,0.25,0.2,0.1$ c.c. of sodium oleate solution is employed (using tubes containing about 10 c.c.) and 1 c.c. of a 1 to 10 solution of guinea-pig serum and 1 c.c. of serum to be examined heated to $56 \mathrm{C}$. This is allowed to stand for one hour at $3 \% \mathrm{C}$. to bind the complement, then 0.5 of amboceptor thinned out to a $1: 200$ solution is added ( 2 to 3 amboceptor units) and 1 c.c. of 5 per cent. sheep's blood (normal salt solution). Each tube is filled to 5 c.c. with normal salt solution. The tubes are then kept at $3 \% \mathrm{C}$. in the thermostat and hemolysis observed for about two hours.

The inhibitory zone in our tests lay between 0.4 and 0.3 c.c. somewhat above the limits of Altmann and Sachs (0.25 c.c.). It is necessary to use a control test each time to determine this zone, as the sodium oleate varies somewhat in its dissolving power.

We give the results in a few of our cases to show how reactions are tabulated.

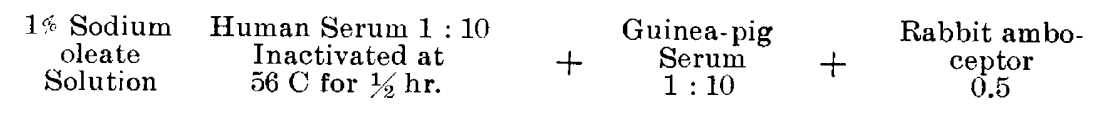

\begin{tabular}{|c|c|c|c|c|c|}
\hline $\begin{array}{l}\text { Solution. } \\
0.6\end{array}$ & Case. 1. & Case 2. & Case 3. & Case 24. & Case 31. \\
\hline $0 . \overline{3} \ldots$ & Complete. & $\begin{array}{l}\text { Complete. } \\
\text { Complete. }\end{array}$ & $\begin{array}{l}\text { Complete. } \\
\text { Complete. }\end{array}$ & $\begin{array}{l}\text { Complete. } \\
\text { Complete. }\end{array}$ & $\begin{array}{l}\text { Complete. } \\
\text { Complete. }\end{array}$ \\
\hline 0.4 & 0 & 0 & Complete. & 0 & Complet \\
\hline 0.3 & 0 & Trace. & Complete. & 0 & Complete. \\
\hline $0.2 \overline{\bar{j}}$ & 0 & Complete. & Complete. & 0 & Almost. \\
\hline 0.2 & 0 & Complete. & Complete. & 0 & 0 \\
\hline 0.1 & Trace. & Complete. & Complete. & 0 & Complete. \\
\hline 0.0 & Complete. & Complete. & Complete. & Complete. & Complete. \\
\hline
\end{tabular}

CASE 1.-F. Paresis. History of syphilis. Reaction positive at 0.4 .

CASE 2.-B. Paresis. History obscure. Reaction positive at 0.4 .

CASE 3.-T. G. Tertiary syphilis. History negative. Reaction negative.

CASE 4--G. H. Suspected syphilis. No symptoms. Reaction positive.

CASE 5.-T. S. Nocturnal epilepsy. Arteriosclerosis. Reaction negative.

CASE 6.-Mrs. G. R. Suspected syphilis. No symptoms. Husband syphilitic.

Reaction positive.

CASE 7.-Secondary syphilis. Under mercurial treatment. Reaction negative.

Case 8.-J. B. Paresis. Suspected syphilis. Reaction positive.

CASE 9.-J. F. Tabes dorsalis. No history of syphilis. Reaction positive.

CASE 10.-D. O. Tuberculosis. No history of syphilis. Reaction negative.

CASE 11.-J. R. R. Paresis. No history of syphilis. Reaction positive.

CASE 12.-J. P. Me. Paresis. History of syphilis. Reaction positive.

CASE 13.- E. G. S. Paresis. No history of syphilis. Reaction negative. 
CASE 14.-R. M. C. Tabes dorsalis. History not known. Reaction positive. CASE 15.-G. H. E. Paresis. No previous history. Reaction negative.

Case 16.-G. McC. Paresis. History of syphilis. Reaction positive.

Case 17.-G. J. B. Paresis. No previous history. Reaction positive.

CASE 18.-T. L. Tertiary syphilis. No treatment. Reaction positive.

CASE 19.-G. H. Doubtful syphilis. No symptoms. Reaction negative.

CASE 20.-W. M. Tuberculosis. Reaction negative.

CASE 21.-Tertiary syphilis nineteen years ago. Chancre two months ago. Reaction positive.

Case 22.- Secondary syphilis. Not treated. Reaction positive.

CASE 23.-Tertiary syphilis. Ulcers of nose and arm. Reaction positive.

CASE 24.-G. V. Incipient paresis. Reaction positive at 0.4 .

CASE 25.-T. B. Tertiary lues. No symptoms. Reaction positive.

Case 26.-G. W. Paresis. History of syphilis, Reaction positive.

CASE 27.-R. B. Paresis, History of syphilis. Reaction positive.

CASE 28.-R. K. CerebraI syphilis. Reaction positive.

CASE 29.-S. T. Chanere of penis. Spirochetes found. Reaction positive.

CASE 30.-D. M. Syphilitic orchitis. Syphilis in 1887. Reaction positive.

CASE 31.-N. M. Pseudoleukemia. Spirochætæ lymphaticæ. Reaction positive.

Our work, did we not look on it as being merely confirmatory of that of others, would not be conclusive, on account of our having used it with only thirty-one suspected syphilitic patients. In addition to these thirty-one, many others were selected from the surgical wards of the Allegheny General Hospital as absolutely non-syphilitic patients, and all of these were negative. Of the thirty-one cases, twelve were clinically diagnosed as paresis, and ten of these gave a positive reaction, two a negative. Two cases of tabes gave a positive reaction. Thirteen cases were either positive or suspicious cases of lues and three of these were negative. Three others were cases in which lues might have been in question, but all were negative. The last case was one of pseudoleukemia. Thus 85 per cent. of our cases gave a positive reaction. An idea of the significance of the reaction is shown by the outlines of some of our cases:

CASE 6.-A suspicious case that was under mercurial treatment. Husband had had syphilis. Reaction positive.

Case 8.-No organic signs of paresis. Progressive mental symptoms. Grandi. ose delusions with slight alteration of the affective sphere. History of syphilis. Reaction positive.

CASE 21.-Syphilis nineteen years ago. Chancre recently. Suspicion of new infection. Reaction positive.

CAse 24.- - Slight intellectual deterioration and paretic speech. No organic changes. Good history. Reaction positive.

CASE 28.-Consultants divided between cerebral syphilis and tubercular meningitis. Reaction positive.

CASE $31,-A$ well-marked case of pseudoleukemia which gave a positive reaction.

Seven of these patients were from the Woodville County Home 
through the kindness of 1)r. Srodes, and one from St. Francis Hospital through the kindness of Dr. Hersmann.

The results obtained by those who lave examined large numbers of sera are quite uniform, namely, that about so per cent. of syphilitic individuals irrespective of the type of syphilis, give a positive reaction, and that the blood of patients who positively lave a non-syphilitic disease invariably gives a negative reaction. (ritron, for instance, reports on 306 cases; 156 of these were non-syphilitic, and all of the latter gave a negative reaction; 108 were of different types of lues, of which $r t$ per cent. were positive; 43 cases were of paresis and tabes, of which ro per cent. were positive. Fleischmann reports 192 cases, 160 of which, or 84 per cent., were positive. Blaschko reports his cases according to the stage, and his positive results were as follows:

90 per eent. initial stage.

98 per cent., first stage.

91 per cent., late stage, without symptoms.

57 per cent., late stage, without symptoms.

60 per cent.. cerebrospinal symptoms.

He endearors to show by this that the reaction is most positire at the time that the syphilis is most florid, and decreases in its positiveness as the clinical evidence of the syphilis diminishes.

Although results differ somewhat, different observers agree in accepting the value of this reaction when positive. When the result is negative, however, it can not be accepted as indicating anything. The fact that the results in tabes and paralytic dementia are so strikingly positive-though these are chronic discases in which the etiologic factor is one which has been present with the patient for years-indicates very strongly that we must take these diseases from the eategory of metasyphilitic and parasyphilitic diseases and group them positively as discases of luetic origin, and more than this, discases in which there is still an active agent at work.

We can believe this, and still subscribe to the doctrine that this test is a reaction for all protozoan discases, for there are no other diseases of protozoan origin, as far as we know, that clinically might be confused with diseases whi(c) are of luetic origin. It has recently been reported that this reaction is positire in scarlet ferer, which would scem to indicate that this is a protozoan disease.

Acepting, therefore, as we must, the reliability of the serum diagnosis of syphilis when the result is positive, its incaleulable value, prognostically considered, can readily be seen. Instead of unfortunate individuals being compelled to go through years of their lives not knowing whether they have had, or have not had, syphilis, they can now discorer 
whether they have been infected with this dreaded discase. And more than this, a phrsician can ascertain the results of active treatment and inform the patient accordingly. The different sociological questions concerning the marriage of syphilitic patients, their future prospects and their offspring, and the detection of syphilis in wet-nurses, may also be answered by means of "urther stuly of this method of diagnosis.

Keenan Building.

\section{BIBLIOGRAPII:}

1. Bordet and Gengou: Ann. de l'Inst. Pasteur. 1901, xr, 289; 1902, xvi.

2. Gay: Centralbl. f. Bakteriol., 1905. No. 5. 39 .

3. Moreschi: Berl. klin. Wehnschr., 1905, No, 37.

4. Neisser and Sachs: Berl. klin. Wehnsehr.. 1905. No. 44.

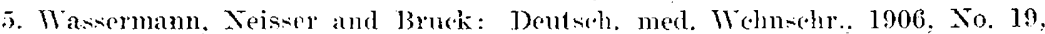
1. 745

6. Neisorr. Bruck and Schueht: ])eutsch. med. Wchnschr., 1906. No. 48, p. 1937.

¡. Wassermamn, Neisser. Bruck and Schucht: Ztsehr. f, Hyg., 1906, 1v, 451.

8. Wassermann and Plaut: Deutsch. med. Wehnsehr., 1906, No. 44.

9. Schultzo: Berl. klin. Whinschr.. 1907, No. 5.

10. Marie and Levaditi: ]3ull et mém. Soce med. d. hôp. de Paris. Dec. 21. 1906 , 1. 13330 .

1. Xoreanroth and Stert\%: Virchow's Arch. f. path. Anat.. chxwrii, No. 1.

12. Citron: Deutsch. mel. Wrhnsehr., 1907. No. 29, p. 1165.

13. Wassermann and Meis: Jentsch, med. Wohnschr, 1907, No, 32.

14. Meier: Berl. klin. Wrhnsehr., 1907, No. 51.

15. Fischer and Meier: Deutsch med. Wohnschr., ]907, xxi, No, 2, p. 138.

16. Weil: Wiener klin. Wohnsehr.. 1907, No. 18, p. 527.

17. Weil and Braun: Berl. klin. Wehnsehr.. 1907, No. 49, p. 1sio.

18. Plaut: Miinchen. med. Wr.hnsehr.. 1907. No. 30.

19. Kraus and Volk: Wien. klin. Wehnschr., 1907. No. 17, p. 515.

20. Weyganilt: Deutsch. med. Wrehnschr., 1907, p. 1239.

21. Tandsteiner. Mü̈lej and l'̈̈tzl: Deutseh. med. Wohnschr.. 1907. p. j]t.

2.2. Tandsteiner: XIV Internat. Kongress f. Hyg.. ete.. Berlin. 1907.

23. Landsteiner, Mäller and Paitzl: Wien. klin. Wehnschr., 1907, No. 50. p. 1565.

24. Tevaditi and Tamanoushi: Compt. rend. Soe. de biol. 1907, Xo. 38. p. T40.

25. Porges and Neubaner: Binchem. Ztschr. 1907 , vii, Nos. 1 and 2.

26. Landsteiner and Stankovic: Centralbl. f. lakteriol. 1906, xli. p. 108.

27. Waxermann and citron: Ztachr. f. exper. Path. w. Therap., 1907, iv, p. 428

28. Seligmann: Berl. klin. Wchnschr.. 1907. No. 32.

29. Michaclis: Berl. klin. Wohms.hr.. i907. No. 46.

30. Fornet: Deutsch. med. Wehnschr.. 1908. No. 19.

31. Muehsam: 13erl. klin. Wrhnschr., 1908, No. 1.

32. Fleishmann: Berl. klin. Wehnsehr., 1908. No. 10.

33. Sachs and Altmann: Berl. kljn. Wehns.hr.. 1908. No. 10.

34. Peritz: Berl. klin. Whherhr., 1908, No. 2.

35. Benecke: Berl. klin. Wehnsehr., 1908. No. lis.

36. Cohen: Berl. klin. W(hnschr., 1908, No. 15.

37. Blaschk: Berl. klin. Wohnschr., 1008, No. 17.

38. Bawer: Berl. klin. Wehnschr.. 1908, No. 17.

39. Fischer: Berl. klin. W'hnschr., 1908, No. 4.

40. Michaelis: Berl. klin. Wichnsehr., 1908, No. 6.

41. Wollstein and Lamar: Tue Inciures Ixt. Men., 1!08, i. No. 3. 